\title{
Attitude towards tobacco consumption among residents of Dhankuta Municipality of Nepal
}

\author{
Sah RB \\ Associate Professor, School of Public Health and \\ Community Medicine, BPKIHS, Dharan, Nepal
}

\author{
Jha $\mathbf{N}$ \\ Professor \& Chief, School of Public Health and \\ Community Medicine, BPKIHS, Dharan, Nepal
}

\section{ABSTRACT}

The use of tobacco is a major cause of preventable mortality. The estimated number of smokers is 1.1 billion. Of these, 700 million men and 100 million women are in developing countries. The objective of this study was to find out attitude towards tobacco consumption among residents of Dhankuta Municipality. The cross-sectional study was conducted among the residents of Dhankuta Municipality where 205 households were taken as subjects. Pretested semi-structured questionnaire was administered to the study subjects and face to face interview was conducted. The collected data was entered in MS Excel 2000. The quantitative data was analyzed using Statistical Package for the Social Sciences (SPSS) software package. The study subjects consist of $50.2 \%$ of male and $49.8 \%$ of female. Regarding respondent's education, study population showed high level of SLC and above (40.5\%) followed by below SLC (36.1) and very less was illiterate $(14.1 \%)$. Majority of the respondents think that there should be ban of the advertising of tobacco products $(87.3 \%)$ and smoking in public places (79\%). Almost $67 \%$ of respondents think that patient's chances of quitting smoking will be increased if health professionals will give advice to patients. Almost $72.6 \%$ of the study population feel cut down tobacco use and $80.3 \%$ feel guilty about this habit. Almost $65.8 \%$ have tried to discontinue tobacco consumption. We conclude that the residents of Dhankuta reflect good attitude towards cessation of tobacco but poor practice to prevent of tobacco consumption.
Keywords: Attitude, Tobacco consumption, Residents, Dhankuta Municipality

\section{Introduction}

Tobacco use is one of the important preventable causes of death and a leading public health problem all over the world. Tobacco kills one person every 6 seconds and causes one in ten deaths among adults worldwide which amounts to more than 5 million people a year. Second hand tobacco smoke is estimated to cause about 600,000 premature deaths word wide. ${ }^{1}$

Tobacco use is growing fastest in the low-income countries due to steady population growth coupled with tobacco industry targeting and ensuring that millions of people become fatally addicted each year. More than $80 \%$ of the world's tobacco related deaths are estimated to be in low and middle-income countries by $2030 .^{2}$

In Nepal, proportional mortality from chronic noncommunicable diseases (NCDs) is $42 \%{ }^{3}$ Such high mortality may be due to high smoking rates in the population aged 18 years and above. ${ }^{4}$ The prevalence rate of tobacco use from small scale surveys ranges from $20 \%$ of $72 \%$ among different population groups. $^{5,6}$ In Nepal, data shows $39.5 \%$ of males and $23.8 \%$ of females smoke with about 7000 million cigarette sticks consumed in Nepal in $2000 .^{7,8}$ The main form of tobacco consumption in Nepal is cigarettes; though other type of smoking tobacco i.e., 'bidis' (hand-rolled cigarettes that contain 
unprocessed tobacco) are also common. ${ }^{9}$ Therefore this study was designed to find out attitude towards tobacco consumption among residents of Dhankuta Municipality.

\section{Methods}

The cross-sectional study was conducted from $1^{\text {st }}$ July 2014 to $30^{\text {th }}$ April 2015 among the residents of Dhankuta municipality of Nepal Dhankuta is located in the eastern geographical region of Nepal. This research was based on random selection of the study area Dhankuta municipality. A National survey revealed that the prevalence of tobacco use was 33\% (Khan $\mathrm{S}$ et al in India in 2013) ${ }^{10}$, more than that $45 \%$ (Karki YB et al Nepal in 2002) ${ }^{11}$ and highest $52.07 \%$ (Zahiruddin QS et al in India in 2011) ${ }^{12}$. So taking lower value $33 \%$ of prevalence of tobacco use, sample size was calculated at $95 \%$ CI \& $80 \%$ powers then it became 205 persons aged above 17 years. There are 9 wards in Dhankuta Municipality. Among 9 wards, 5 wards was randomly selected. The list of households of five selected wards was prepared and equal number of households (41) from each ward was selected on the basis of simple random sampling.

Ethical clearance was taken by Institutional Ethical Review Board of B P Koirala Institute of Health Sciences, Dharan, Nepal. Participants were first explained the purpose of study, its implications and assurance about the confidentiality of the information provided was given to the participants. Name of the individuals or participating group was not disclose after the study.

Pretested semi-structured questionnaire was administered to the study subjects in the presence of investigator and face to face interview was conducted. Written permission was taken from concerned authority (head of house) and the participants of the study. Those individuals who were available after three visits and willing to give written consents were included in the study.

The collected data was coded and entered in Microsoft Excel 2000. The quantitative data was analyzed using Statistical Package for the Social Sciences (SPSS) software package, and percentage, proportion and test of significance was applied wherever applicable.

\section{Results}

\section{Socio-demographic characteristics}

A study subject consists of 205 persons aged above 17 years. The study subjects consist of $50.2 \%$ of male and $49.8 \%$ of female. Study population showed high level of Janajati ethnic group (40.5\%) followed by Brahmin/Chhetri (36.1\%), Kirati (14.1\%), Dalit (6.3\%) and Terai caste (2.9\%). Regarding respondent's occupation, study population showed high level of service $(30.2 \%)$ and very less was farmer (14.1\%) (Table1). 
Table 1: Study population by socio-demographic characteristics $(\mathrm{N}=\mathbf{2 0 5})$

\begin{tabular}{|c|c|c|}
\hline Characteristics & Frequency & Percent \\
\hline $\begin{array}{l}\text { Age } \\
17-40 \text { years } \\
41-59 \text { years } \\
\geq 60 \text { years }\end{array}$ & $\begin{array}{c}140 \\
53 \\
12 \\
\end{array}$ & $\begin{array}{c}68.3 \\
25.9 \\
5.9 \\
\end{array}$ \\
\hline $\begin{array}{l}\text { Gender } \\
\text { Male } \\
\text { Female }\end{array}$ & $\begin{array}{l}103 \\
102 \\
\end{array}$ & $\begin{array}{l}50.2 \\
49.8 \\
\end{array}$ \\
\hline $\begin{array}{c}\text { Religion } \\
\text { Hindu } \\
\text { Others (Buddhist, Christian, Muslim) }\end{array}$ & $\begin{array}{c}181 \\
24\end{array}$ & $\begin{array}{l}88.3 \\
11.7 \\
\end{array}$ \\
\hline $\begin{array}{c}\text { Ethnicity } \\
\text { Brahmin/ Chhetri } \\
\text { Kirati } \\
\text { Janajati } \\
\text { Dalit } \\
\text { Terai caste }\end{array}$ & $\begin{array}{c}74 \\
29 \\
83 \\
13 \\
6\end{array}$ & $\begin{array}{c}36.1 \\
14.1 \\
40.5 \\
6.3 \\
2.9\end{array}$ \\
\hline $\begin{array}{l}\text { Education of respondents } \\
\text { Illiterate } \\
\text { Below SLC } \\
\text { SLC and above }\end{array}$ & $\begin{array}{l}48 \\
74 \\
83\end{array}$ & $\begin{array}{l}23.4 \\
36.1 \\
40.5\end{array}$ \\
\hline $\begin{array}{c}\text { Occupation of respondents } \\
\text { Service } \\
\text { Business } \\
\text { Farmer } \\
\text { Housewife } \\
\text { Others (students, abroad, labor, tailor, } \\
\text { carpenter) }\end{array}$ & $\begin{array}{l}62 \\
51 \\
29 \\
32 \\
31\end{array}$ & $\begin{array}{l}30.2 \\
24.9 \\
14.1 \\
15.6 \\
15.1\end{array}$ \\
\hline $\begin{array}{c}\text { Economic status } \\
\text { Below poverty line }(<1.25 \text { US\$ }) \\
\text { Above poverty line }(\geq 1.25 \text { US } \$)\end{array}$ & $\begin{array}{c}127 \\
78\end{array}$ & $\begin{array}{l}62.0 \\
38.0\end{array}$ \\
\hline Total & 205 & 100.00 \\
\hline
\end{tabular}

\section{Attitude towards tobacco consumption among study population}

Majority of the study population think that there should be ban of the advertising of tobacco products and smoking in public places. Most of the respondents think that if health professionals will give advice about smoking cessation to patients then patient's chances of quitting smoking will be increased (Table 2). 
International Journal of Trend in Scientific Research and Development, Volume 1(4), ISSN: 2456-6470 www.ijtsrd.com

Table 2: Attitude towards tobacco consumption among study population $(\mathbf{N}=\mathbf{2 0 5})$

\begin{tabular}{|c|c|c|}
\hline Characteristics & Frequency & Percent \\
\hline Should be ban of the advertising of tobacco & & \\
products & 179 & 87.3 \\
Yes & 26 & 12.7 \\
No & 162 & 79.0 \\
Yes & 43 & 21.0 \\
No & & \\
Banning of smoking in public places & 138 & 67.3 \\
\hline Health professionals have role in giving advice & 67 & 32.7 \\
about smoking cessation to patients & & \\
Yes & & \\
No & 128 & 62.4 \\
\hline Are patient's chances of quitting smoking & $\mathbf{7 7}$ & 37.6 \\
increased if a health professional advises him or & $\mathbf{1 0 0 . 0}$ \\
her to quit & $\mathbf{2 0 5}$ & \\
Yes & & \\
No & & \\
Total & & \\
\hline
\end{tabular}

\section{Attitude towards tobacco use among tobacco consumer}

Among 205 study population, almost 117 (57.1\%) of respondents were found to be consuming tobacco in Dhankuta Municipality. Majority of tobacco consumer feel cut down tobacco use and guilty about this habit. Most of the tobacco consumer need to consume tobacco first in the morning and feel energized (very active) after tobacco consumption. Majority of the tobacco consumer have tried to discontinue tobacco consumption (Table 3).

Table 3: Attitude towards tobacco use among tobacco consumer $(\mathrm{N}=117)$

\begin{tabular}{|l|c|c|}
\hline \multicolumn{1}{|c|}{ Characteristics } & Frequency & Percent \\
\hline $\begin{array}{l}\text { Feel cut down tobacco use }(\mathrm{n}=117) \\
\text { Yes }\end{array}$ & 85 & 72.6 \\
No & 32 & 27.4 \\
\hline Annoy when people criticize your habit $(\mathrm{n}=117)$ & & \\
Yes & 95 & 81.2 \\
No & 22 & 18.8 \\
\hline Feel guilty about your habit $(\mathrm{n}=117)$ & 94 & 80.3 \\
Yes & 23 & 19.7 \\
No & & 55.6 \\
\hline Need to consume tobacco first in the morning & & 44.4 \\
(n=117) & 65 & \\
Yes & 52 & 35.0 \\
No & & \\
Tension free & 41 & \\
\hline Feel after tobacco consumption $(\mathrm{n}=117)$ & & \\
\hline
\end{tabular}



www.ijtsrd.com

\begin{tabular}{|c|c|c|}
\hline Energized (very active) & 68 & 58.1 \\
Satisfied & 8 & 6.8 \\
\hline Have you tried to discontinue (n=117) & 77 & 65.8 \\
Yes & 40 & 34.2 \\
No & 74 & \\
Interested in quitting (n=117) & 43 & 63.2 \\
Yes & $\mathbf{1 1 7}$ & 36.8 \\
\hline No & & $\mathbf{1 0 0 . 0}$ \\
\hline
\end{tabular}

\section{Discussion}

Tobacco use is still a serious public health problem in the world. It kills nearly 6 million people and is responsible for hundreds of billions of dollars of economic damage worldwide each year. If current trends continue, by 2030 tobacco will kill more than 8 million people worldwide each year, and over the course of the 21st century, tobacco use could kill approximately a billion people unless urgent action is taken. ${ }^{13}$

Majority of respondents (87.3\%) think that tobacco use can be control by banning of the advertising of tobacco products. A study conducted by Pantsidis GM et al showed that there should be a complete ban of the advertising of tobacco products $(74.2 \%)^{14}$ which is lower than our study. The fact that majority of respondents mostly agree with banning of tobacco sales to minors and banning of advertisement of tobacco products. ${ }^{14}$ The prevalence of smoking among minors is alarmingly high in Greece, while access to the tobacco market and exposure to tobacco advertising is almost universal. ${ }^{15}$ Although laws have been adopted prohibiting tobacco sales to minors, it appears that this has not been sufficient to prevent smoking, but it may help to reduce it. ${ }^{16}$ The WHO also promotes the banning of advertisement of tobacco products $^{13}$ while it emphasizes the importantance of promotion of anti-smoking advertisements and the implementation of health education projects with the participation of health professionals. ${ }^{17}$

Majority of respondents (79\%) think that there should be banning of smoking in public places. A study conducted by Pantsidis GM et al showed there should be useful if banning of smoking will be done in all enclosed public places $(88.6 \%)^{14}$ which is higher than our study. Majority of respondents mostly agree with banning of smoking in all enclosed public places is encouraging. ${ }^{14}$

This study showed that the health professionals have important role in giving advice about smoking cessation to patients (67.3\%). A study conducted by Pantsidis GM et al also showed health professionals have a role in giving advice or information about smoking cessation to patients $(98.7 \%)^{14}$ which is higher than our study. Health workers are regarded as the most reliable source of advice and information on health issues and they act as role models for the rest of society. ${ }^{18}$ Several studies have demonstrated the crucial role of health workers in the promotion of smoking cessation through counseling. ${ }^{19,20}$ 
Majority of respondents $(62.4 \%)$ think that the chance of quitting smoking is increased if a health professional advises them to quit. A study conducted by Pantsidis GM et al also showed that the chance of quitting smoking increased was $80.8 \%{ }^{14}$ if a health professional advises them to quit, which is higher than our study.

This study showed that the majority of smokers (63.2\%) was interested in quitting smoking. A study conducted by Bhimarasetty DM et al which showed that about $3 / 4$ ths of smokers $(74.4 \%)$ were willing to quit smoking which is greater than our study. ${ }^{21}$ More than half of the smokers willing to quit and were showing interest to join smoking cessation programs. Among these subjects nearly two-thirds (64\%) of smokers want such programs to be conducted in public places. Tobacco cessation interventions are clinically effective and cost- effective, relative to other commonly used disease prevention intervention and medical treatments. ${ }^{22}$ School and college-based interventions such as counseling to promote cessation among current users and tobacco education to prevent initiation are necessary. ${ }^{23}$ Limitation of this study was the data were based on the self-report of respondents, who might underreport or over-report their behaviour or attitudes.

\section{Conclusion}

Residents of Dhankuta reflect good attitude towards cessation of tobacco but poor practice to prevent of tobacco consumption. Tobacco consumption was prevalent among the residents of Dhankuta Municipality. Therefore the problem of tobacco consumption can control by bann the production, awareness program and nicotine therapy. This means that treatment centres should be organised to treat dependence and to improve strategies to increase public awareness. Effective smoking cessation programmes may need to involve family members who may also be smokers.

\section{Acknowledgement}

We would like to thank to School of Public Health and Community Medicine for approval of our research work. Our gratitude and sincere thanks to all the participants of study from Dhankuta for their kind co-operation.

\section{References}

1. WHO Report on the global tobacco epidemic 2009. Available from: http:/www. who. Int/tobacco/mpower/2009/en/.

2. WHO Report 2008. [Cited 2013 May 27]. Available from: http:// www. who. int/ whr/ 2008/en/.

3. WHO South-East Asia Region: WHO World Health Survey. WHO Global InfoBase Version: 1.292 beta 2001 .

4. Binu VS, Subba SH, Menezes RG, Kumar G, Ninan J, Rana MS. Smoking among Nepali youthprevalence and predictors. Asian Pac J Cancer Prev 2010; 11: 221-226.

5. Niraula SR. Tobacco use among women in Dharan, eastern Nepal. J Health Popul Nutr 2004; 22: $68-74$.

6. Jha NP, Upadhyaya MP, Lakhey S, Yadav BK, Baral DD, Gautam A. Smoking and smokers in Sunsari, Nepal. J Nep Med Assoc 1999; 38:7-13. 
7. Tobacco Nepal. Available from: [http://www.searo.who. int/LinkFiles/ Regional_ Tobacco_ Surveillance__ System_Country_ Profiles_Nepal.pdf.

8. Karki YB. Review and situation analysis for comprehensive national tobacco control in Nepal. Available

from:

http://www.searo.who.int/LinkFiles/NMH_CNTC n epal.pdf].

9. Shimkhada R, Peabody JW. Tobacco control in India. Bull World Health Organ 2003; 81: 48-52.

10. Khan S, Mahmood SE, Sharma HK, Khan F. Tobacco use among medical students: are they the role models of the society. Journal of Clinical and Diagnostic Research 2013; 6: 605-607.

11. Karki YB. Review and situation analysis for comprehensive National Tobacco Control in Nepal 2002; available from: http://www.searo.who.int/Link Files/NMH CNTCnepal pdf. (Accessed on 26 July, 2015)

12. Zahiruddin QS, Gaidhane A, Bawankule S, Nazli K, Zodpey S. Prevalence and pattern of tobacco use among tribal adolescents: Are tobacco prevention messages reaching the tribal people in India? Ann Trop Med Public Health 2011; 4: 7480 .

13. World Health Organization. WHO report on the global tobacco epidemic, 2011: warning about the dangers of tobacco. World Health Organization, Geneva, 2011.

14. Pantsidis GM, Papageorgiou DL, Bouros D. Smoking habits, attitudes and training among medical students of the Democritus University of Thrace. Pneumon 2012; 2 (25):208-218.
15. Kyrlesi A, Soteriades ES, Warren CW. Tobacco use among students aged 13-15 years in Greece: the GYTS project. BMC Public Health 2007; 7: 3.

16. Stead LF, Lancaster T. Interventions for preventing tobacco sales to minors. Cochrane Database Syst Rev 2005; (1): CD001497.

17. Vasilopoulos A, Roupa Z, Gourgoulianis K. The influence of advertising messages on the smoking habits of teenagers. Pneumon 2011; 24:188-193.

18. Warren CW, Asma S, Lee J, Lea V, Mackay J. The GTSS Atlas. CDC Foundation, Atlanta, 2009.

19. Fang CY, Ma GX, Miller SM, Tan Y, Su X, Shive S. A brief smoking cessation intervention for Chinese and Korean American smokers. Prev Med 2006; 43: 321-324.

20. World Health Organization. WHO Report on the Global Tobacco Epidemic, 2008: The MPOWER package. World Health Organization, Geneva, 2008.

21. Bhimarasetty DM, Sreegiri S, Gopi S, Koyyana S. Perception of young male smokers in visakhapanam about tobacco use and control measures. Int J Res Dev Health 2013; 1(3): 12935.

22. Report on tobacco control in India, MOHFW. [Cited 2013 July 27]. Available from: http://mohfw.nic.in/WriteReadData/1892s/911379 183Toba ccocontroin India_10D ec 04. Pdf. Sreeranmareddy CT, Kishore P, Paudel J, Menezes RG. Prevalence and correlates of tobacco use amongst junior collegiates in twin cities of western Nepal: a cross sectional questionnaire- based survey. BMC Public Health 2008; 8: 97. doi: 10.1186/ 1471-24588-97. 